\title{
The Socio Economic Dimensions of Women in India
}

\author{
Mr. Sreenivas Savvasi ${ }^{1}$, Dr. Prabhakar Varre ${ }^{2}$ \\ ${ }^{I}$ Faculty Member, Dept. of Commerce \& Business Management, GVJC, Hanamkonda, WARANGAL. \\ ${ }^{2}$ Faculty Member, Dept. of Economics, GJC, Nekkonda, WARANGAL
}

\begin{abstract}
The principle of gender equality is enshrined in the Indian constitution in its preamble Fundamental Rights, Fundamental Duties and Directive Principles. The First Prime Minister of India stated that "when the women moves forward, the family moves, the village moves, and the Nation moves". Within the framework of a democratic policy, our Laws, development policies, and programs have aimed at women's advancement on different spheres. From the Fifth Five Year Plan (1974-78) onwards, there has been a remarkable shift in the approach to women's issues from welfare to development. In recent years, the empowerment of women has been recognized as the central issue in determining the status of women. The National Commission for women was set up by an act of Parliament in 1990 to safeguard the right on legal entitlements of women. The 73rd and 74th Amendments (1993) to the Constitution of India have provided for reservation seats in the local bodies of Panchayats and Municipalities for Women, laying a strong foundation for their participation in decision making at the local levels.
\end{abstract}

\section{Introduction:}

Social development is inclusive of economic development and emphasizes on political and cultural aspects also. Entrepreneurship among women has been a resent concern and has become a force to attain empowerment. During the past few decades the political of women are being uplifted in the form of entrepreneurship by setting up small and medium scale enterprises, not only confining to urban areas, but also in rural areas. Unleashing various barriers, Indian women are striking a balance between traditional values of the society in transition through playing dual responsibility at home and at the work place.

The principle of gender equality is enshrined in the Indian constitution in its preamble Fundamental Rights, Fundamental Duties and Directive Principles. The First Prime Minister of India stated that "when the women moves forward, the family moves, the village moves, and the Nation moves".

Within the framework of a democratic policy, our Laws, development policies, and programs have aimed at women's advancement on different spheres. From the Fifth Five Year Plan (1974-78) onwards, there has been a remarkable shift in the approach to women's issues from welfare to development. In recent years, the empowerment of women has been recognized as the central issue in determining the status of women. The National Commission for women was set up by an act of Parliament in 1990 to safeguard the right on legal entitlements of women. The $73^{\text {rd }}$ and $74^{\text {th }}$ Amendments (1993) to the Constitution of India have provided for reservation seats in the local bodies of Panchayats and Municipalities for Women, laying a strong foundation for their participation in decision making at the local levels.

India has also ratified various international conventions and human rights instrument committing to secure equal rights for women. Key among them is the ratification of the Convention of the Elimination of All Forms of Discrimination against Women CEDAW-1975 in 1993. The Mexico plan of Action (1975). The Nairobi Forward looking strategies (1985). The Beijing Declaration as well as the Platform for Action (1995), has been unreservedly endorsed by India for appropriate follow up. The women's movement with a widespread network of Non-Government Organizations which have strong grass roots presence and deep insight into women's concerns has inspired many initiatives for the empowerment of women.

However, there still exists a wide gap between the goals enunciated in the constitution, legislation, policies, plans, programs, and related mechanisms on the one hand the situational reality of the status of women in India, on the other. This has been analyzed extensively in the Report of the committee on the status of women in India, "towards Equality" (1974), and highlighted in the National perspective plan for women (1988-2000), and the Shramshakti Report (1988).

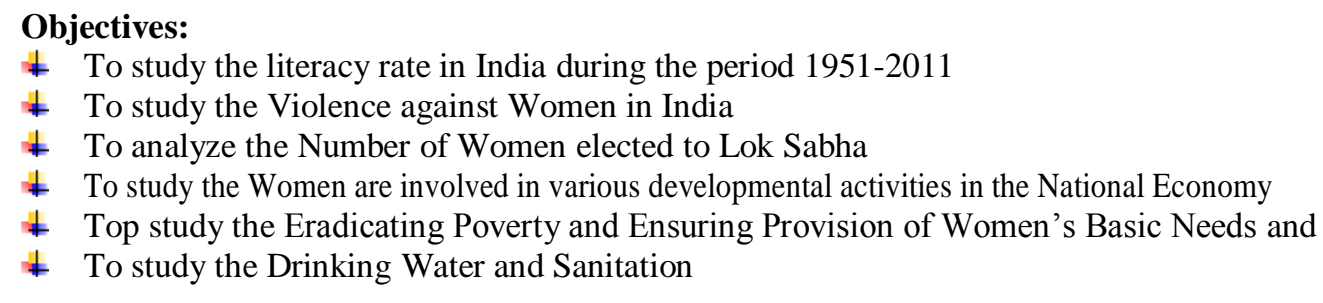




\section{Research Methodology:}

The data collected for the study includes secondary data. The various sources used to collect secondary data include research papers, journals, and various other websites. The secondary data collected is analyzed using various statistical tools and techniques.

Gender disparity manifest itself in various forms, the most obvious being the trend of continuously declining female ratio on the population during last few decades. Social stereotyping and violence at the domestic and societal levels are some of the other manifestations. Discrimination against girl children, adolescent girls and women still persists, in most of the communities especially among poorer sections. Consequently, the access of women majority of who are on the rural areas and in the informal, unorganized sector, education health and productive resources, among others, is inadequate. Therefore, they remain largely marginalized, poor and socially excluded. So far as literacy of women is concerned, it is very low. Table-1 presents the literacy rates in India. See Table -1.

TABLE -1

\section{LITERACY RATE IN INDIA: 1951-2011}

\begin{tabular}{|c|c|c|c|c|}
\hline \multicolumn{5}{|c|}{ (Figures in Percentage) } \\
\hline Census Year & Persons & Males & Females & $\begin{array}{c}\text { Male-Female Gap in } \\
\text { Literacy Rate }\end{array}$ \\
\hline 1951 & 18.33 & 27.16 & 8.86 & 18.30 \\
\hline 1961 & 28.30 & 40.40 & 15.35 & 25.05 \\
\hline 1971 & 34.45 & 45.96 & 21.97 & 23.98 \\
\hline 1981 & 43.57 & 56.38 & 29.76 & 26.62 \\
\hline 1991 & 52.21 & 64.13 & 36.29 & 24.84 \\
\hline 2001 & 65.38 & 75.85 & 54.16 & I6.68 \\
\hline
\end{tabular}

Source: Census of India, Part II, 2011.

The problem of women's illiteracy has also been exacerbated due to low enrolment and high dropout rates among girls who enter the formal system of education. While the enrolment of girls in the schools has shown a steady increase, it is still not commensurate with the enrolment rate of boys. The dropout rate among girls, particularly those who live in rural areas, continues to be very high.

In the light of these facts, major reasons for low literacy rate among women are listed below:

* Early marriage and dowry

* Reluctance to send girls out of the house after puberty.

* High intensity of poverty and parent's inability to bear education expenses.

Lack of access to schools.

* Shortage of women teachers.

* Lack of infrastructure facilities which lead to low enrolment and large dropouts.

* Need for girls to help in the farms or family occupation or household chores or responsibility of looking after younger siblings.

In this background, having taken stock of national and inter national developments and after a series of consultants with members of parliament. State Government, Non-Governmental Organizations, Women's Organizations, Social Activists, Researchers and other experts in the Country, this policy has been drawn up. The goal of this policy is to learn about the advancement, development and empowerment of women. This is to be achieved by changing societal attitudes and elimination of all forms of gender based discrimination, active participation of women in all spheres of life, incorporation of gender perspectives, translation of dejure equality of women into de-facto equality and affirmative action, wherever necessary.

The positive features of Indian Culture and Tradition which reiterate the dignity and respect for women will be reinforced in the endeavour to active social harmony. Through appropriate programs, women and men will be made frequently aware of their social responsibilities as changed agents. Their role as promoters of progressive values and respect for humanity will be emphasized therein. The policy will be widely disseminated so that a meaningful partnership is established with all sections of civil society, to achieve its goals. There is tremendous violence against women recently for one cause or the other. That is discussed here how to eliminate the violence.

\section{Violence against Women in India:}

All forms of violence against Women, particularly sexual abuse and violence, including through recourse to costumes, traditions or practices, shall be eliminated. Mechanisms/Schemes for assistance will be created and strengthened for the rehabilitation of the victims of violence. Institutions and mechanisms responsible for elimination of violence against women and taking action against the perpetrators of such 
violence will be strengthened, and encouraged. Not only that the violence and misbehavior attitudes towards women but also discrimination against women to be permanently eliminated.

Recognizing the equal entitlement of women and men to human rights and fundamental freedoms in all spheres, political, economic social, civil etc., no discrimination shall be allowed on Law or practice against women. Equal rights for women will be ensured in respect of access to health care and quality education at all levels, career and vocational guidance employment, equal remuneration, occupational health and safety, social security, health care and places at public offices. All forms of discrimination against the girl child and violation of her rights shall be eliminated by undertaking strong measures including punitive ones. These relate to strict enforcement of Laws against pre-natal sex selection and foeticide, female on fanaticizes, child marriage, and abuse and child prostitution. Removal of discrimination in the treatment of the girl child on the family and outside, and projection of a positive image of the girl child will be actively fostered. There will be special emphasis on the needs of the girl child and earmarking of substantial investments in the areas relating to food and nutrition health and education including vocational education. In implementing programmes for eliminating child labour, there will be a special focus on the girl children, as the today's child is tomorrow's youth and today's girls are also tomorrow's mothers.

\section{Empowerment of Women:}

A synergy of development measures will be affected on affirmative action designed for the holistic empowerment of women. Women will be given complete and equal access to and control over factors contributing to such empowerment, particularly, health, education imformation, life long learning for selfdevelopment, vocational skills, employment and income earning opportunities, technical services, land and other forms of property, including through inheritance, common property resources, credit, technology and markets etc. the empowerment of women is ensured if they are allowed in to the decision making, including political participation at all levels and in all processes will be ensured for the achievement of the goal of empowerment. All such measures will be taken to guarantee women equal access to and full participation in all decision making bodies at every level, in the private and public sectors, including the legislative executive, Judicial, local, corporate, statutory bodies, as also advisory commissions, committees, Boards, Trusts etc. the committee on empowerment of women has the mandate to examine among others, the measures taken by the union government to secure for women's equality of status and dignity in all matters. Table 2 presents the number of women elected to Lok Sabha during $1^{\text {st }}$ to $15^{\text {th }}$ General Elections. It shows a very poor show of participation both absolute and relatively. See, Table 2 and 3

TABLE-2

Number of Women Elected To Lok Sabha

\begin{tabular}{|c|c|c|}
\hline General Elections & No. of Women Elected & Percentage \\
\hline First & 23 & 4.22 \\
\hline Second & 24 & 4.40 \\
\hline Third & 37 & 6.79 \\
\hline Fourth & 32 & 5.87 \\
\hline Fifth & 26 & 4.77 \\
\hline Sixth & $\mathbf{1 8}$ & $\mathbf{3 . 3 0}$ \\
\hline Seventh & 32 & 5.87 \\
\hline Eighth & 46 & 8.44 \\
\hline Ninth & 28 & 5.14 \\
\hline Tenth & 42 & 7.71 \\
\hline Eleventh & 41 & 7.52 \\
\hline Twelfth & 44 & 8.07 \\
\hline Thirteenth & 52 & 9.54 \\
\hline Fourteenth & 45 & 8.26 \\
\hline Fifteenth & $\mathbf{5 9}$ & $\mathbf{1 0 . 8 2}$ \\
\hline
\end{tabular}

TABLE-3

WOMEN MEMBERS OF RAJYASABHA AND THEIR PERCENTAGE (1956-2010)

\begin{tabular}{|l|l|l|}
\hline Year & Number & Percentage \\
\hline 1956 & 20 & 8.62 \\
\hline 1958 & 22 & 9.52 \\
\hline 1960 & 24 & 10.25 \\
\hline
\end{tabular}$\quad$\begin{tabular}{|l|l|l|}
\hline Year & Number & Percentage \\
\hline 1984 & 24 & 10.24 \\
\hline 1986 & 28 & 11.98 \\
\hline 1988 & 25 & 10.59 \\
\hline
\end{tabular}




\begin{tabular}{|l|l|l|}
\hline 1962 & 18 & 7.62 \\
\hline 1964 & 21 & 8.97 \\
\hline 1966 & 23 & 9.82 \\
\hline 1968 & 22 & 9.64 \\
\hline 1970 & 14 & 5.85 \\
\hline 1972 & 18 & 7.40 \\
\hline 1974 & 18 & 7.53 \\
\hline 1976 & 24 & 10.16 \\
\hline 1978 & 25 & 10.24 \\
\hline 1980 & 29 & 11.98 \\
\hline 1982 & 24 & 10.16 \\
\hline
\end{tabular}

\begin{tabular}{|l|l|l|}
\hline 1990 & 24 & 10.34 \\
\hline 1992 & 17 & 7.29 \\
\hline 1994 & 20 & 8.36 \\
\hline 1996 & 19 & 7.81 \\
\hline 1998 & 19 & 7.75 \\
\hline 2000 & 22 & 9.01 \\
\hline 2002 & 25 & 10.20 \\
\hline 2004 & 28 & 11.43 \\
\hline 2006 & 26 & 10.74 \\
\hline 2008 & 28 & 11.98 \\
\hline 2010 & 26 & 10.74 \\
\hline
\end{tabular}

Source: Who's Who Rajya Sabha

Given the low representation of women in politics there has been a consistent demand for more meaningful methods to increase their representation in decision-making bodies. In pursuance of this notion of empowerment of women, the Constitution ( $73^{\text {rd }}$ Amendment) Act and the Constitution ( $74^{\text {th }}$ Amendment) Act reserved seats for women at the grassroots level bodies, namely, the pantheists and municipalities with the hope that these measures will set the trend to provide women their legitimate place in public life. After these amendments, Article $243 \mathrm{D}$ and $243 \mathrm{~T}$ of the Constitution provide that not less than one-third (including the number of seats reserved for women belonging to the Scheduled Castes and the Scheduled Tribes) of the total number of seats to be filled by the direct election in the local bodies (Panchayats and Municipalities) would be reserved for women and such seats may be allotted by rotation to different constituencies in the local bodies. This indeed makes a beginning for the effective participation of women in the decision making process at the grassroots level. And it is facts that in the elections to these local bodies' one million women have been elected every five years. It is but natural that a larger number of women would have participated in these elections and this portrays a very encouraging trend for women's empowerment.

\section{The Women Are Involved In Various Developmental Activities In The National Economy:}

Policies, programs and systems are to be established to ensure mainstreaming of women's perspectives in all development processes, as catalysts, participants and recipients. Coordinating and monitoring mechanisms will be devised to assess from time to time the progress of such mainstreaming. Women's issues and concerns, will, as a result be specially addressed and reflected in all concerned laws, sect oral policies, plans and programmes of action.

Specially planned and well funded sensitization programmes will be conducted on a regular basis for all sections of society. There will be special focus on functionaries of the state in the executive, legislative and judicial wings and in all developmental agencies, governmental and non-governmental. These programmes will be, in a phased manner integrated as part of all ongoing training programmes both in the public and the private sectors.

Media will be used to portray a positive image of girl and women. It will strive to remove demeaning, degrading and negative, conventional stereotypical image of women and violence against women. Legislation media policies and regulatory mechanisms, including codes of conduct etc., will be put in place to address these aspects.

\section{Eradicating Poverty and Ensuring Provision of Women's Basic Needs:}

Since women comprise the majority of people below the poverty line and are very often institutions of extreme poverty, given the harsh realities of intra household and social discrimination, macro economic policies and poverty eradication programmes will be improved. Implementations of such programmes as are already in vogue and women oriented or have special targets for women. New programmes are devised by offering then a range of economic and social option, along with necessary support services to enhance their capabilities. To eradicate poverty and to provide better standard of living food safety, availability and security also needed. The Govt. has chalked out programmes for this also.

In order to satisfactorily cater to the nutritional needs and requirements of household, the public Distribution System is to be strengthened, intra-house-hold discrimination in this regard vis-à-vis girls and women will be sought to be ended through appropriate strategies. Women's participation is to be ensured in the planning, superintendence and delivery of the system. But, recently, the PDs also happens to be a failure in effective distribution of essential commodities and a lot more efforts are needed to strengthen PDs. 


\section{Drinking Water and Sanitation:}

Special attention is to be given to the needs of women in the provision of safe drinking water, sewage disposal, toilet facilities and sanitation with in accessible reach of households. Women's participation is to be ensured in the planning, delivery and maintenance of such services. In the recent decision of the Government of India, the President Announced PURA (i.e., providing urban facilities in the Rural Areas) scheme. If it is successful, the women's lot will be improved. Women will be involved and their perspectives reflected in the policies and programmes for eco-systems management. Considering the impact of environmental factors on their livelihoods and the distribution of labour and time within households, in connection with the collection of fuel and fodder, women's participation will be ensured in the conservation of the environment and control of environmental degradation. Another notable factor is that the majority women are illiterate and uneducated. Uneducated means unscientific essay for women to be empowered.

Programmes are to be strengthened to bring about a greater involvement of women in science and technology. These will be including measures to motivate girls to take up science and technology for higher education and also ensure that development projects with scientific and technical inputs involve women fully. Efforts to develop a scientific temper and awareness towards science are to be provided to make useful citizens. If man is educated only he is benefited. If woman is educated whole family is educated. Therefore all types of education are necessary for women empowerment and independence.

\section{Involvement of Ngos for Women Awareness:}

The voluntary organizations, or associations, federations, trade unions and other Non-Governmental Organizations, Women's Organizations, as well as institutions, dealing with education, training and review of all policies and programmes effecting women are to be involved. Towards this end, they will be provided with support related to resources and capacity building and facilitated to participate activity in the process of the empowerment of women. Their participation should be effective and societal, in upgrading women's skills and abilities.

Gender disaggregated data are to be collected by all primary data collecting agencies of the central and State Governments as well as research and Academic Institutions in the Public and Private Sector. Data and information gaps in vital areas reflecting the status of women are also be filled in by these agencies, to have accurate data.

All Ministries/Departments / Corporations / Banks and Financial Institutions etc., are to be involved to will collect, and maintain / public data related to programmes and benefits on a gender disaggregated basis.

International, regional and sub-regional co-operation towards and empowerment of women is necessary. Through sharing of experiences, exchanges of ideas and technology, networking with institutions and organization and through bilateral and multilateral partnerships, the knowledge improves and makes the women stand before the field of international level.

\section{Conclusion:}

The women population is half of the globe and majority of them are even today suffering with many problems like dowry harassment, Rapes, AIDS, Prostitution so on and so forth. Even after 58 years of Independence, they are not out of the clutches of their counter parts, i.e. men. If they are provided financial sources through permanent, employment or inherited properties or equal political power, they could survive an own feet and to some extent act independently. Even after all these facilities, it may not be possible as they are weakest creatures on the earth. Therefore, the woman empowerment, by words or uttering it or giving speeches on the different for a may not ensure power by self. A concerned effort in necessary from all these facilities, it may not be possible as they are weakest creatures on the earth. Therefore, the woman empowerment, by words or uttering it or giving speeches on the different for a may not ensure power by self. A concerned effort is necessary from all sections to respect their independence (economic, social and political) to stand on their own legs. Then only they can raise their heads before the society in future. The Present UPA Government at the centre tried to provide 33 percent reservation for women through an act in the Parliament but there was no unanimity in the ruling coalition parties itself. Therefore, it was not enacted to empower the women. Some observed that it was a sign of indirect gender bias while others wanted it to be implemented as quickly as possible. However, it was not enacted for the reasons best known to them.

the status of Women in India, 197

[2] G.O.I Shram Shakti Report, 1988

[3] Ranjani K. Murthy, Building women's Capacities, 2001.

[4] Agarwal, S.P. Women's Education in India, 2001.

[5] Pandimuruga Chinnan, K, Women's Education as a tool for rural development, Kurukshetra, September, 2005 p.22

[6] Yogendra Naraian et al., Political Empowerment of Women, I.J.P.A. jan-March 2005. 